\title{
Od metody naukowej do naturalizmu metodologicznego. Ewolucja idei
}

Paul de Vries, w reakcji na pojawienie się kreacjonizmu naukowego i jego rosnącą popularność w konserwatywnych kręgach protestanckich w latach sześćdziesiątych dwudziestego wieku, zaproponował pewien sposób rozumienia nauki, który nazwał „,naturalizmem metodologicznym". Jako profesor filozofii w Wheaton College, znalazł się on w intelektualnym centrum amerykańskiego ewangelikalizmu i chciał zaoferować studentom alternatywę dla kreacjonizmu naukowego, z jednej strony, oraz ,ewolucjonistycznego scjentyzmu”, $z$ drugiej. Zdaniem de Vriesa oba te poglądy przedstawiają zniekształcony obraz nauki i zmanipulowaną wiarę. ${ }^{1}$

* Harry Lee PoE and Chelsea Rose Myтүк, „From Scientific Method to Methodological Naturalism: The Evolution of an Idea", Perspectives on Science and Christian Faith, September 2007, vol. 59, no. 3, s. 213-218, http://www.asa3.org/ASA/PSCF/2007/PSCF9-07Poe.pdf (22.01.2010). Za zgodą Autorów z języka angielskiego przełożyli: Bartosz BŁAszczaK, Gerard Dmuch, Ewa Komorowska, Iwona Kumiszcze, Izabela ObŁaczyńsKa, Katarzyna PıŁka, Radosław Plato, Marika Poprawska, Dariusz Sagan, Karolina Stencel, Katarzyna Szot i Piotr WróBLEWSKI. Przekładu dokonali studenci filozofii na Uniwersytecie Zielonogórskim w ramach translatorium z języka angielskiego, prowadzonego przez mgra Dariusza Sagana. Recenzent: Józef Zon, Katedra Biologii Teoretycznej Katolickiego Uniwersytetu Lubelskiego.

${ }^{1}$ Korespondencja elektroniczna między Paulem de Vriesem a Chelsea Mytyk, 28 kwietnia 2006; Paul DE VRIES, „Naturalizm w naukach przyrodniczych. Perspektywa chrześcijańska”, przeł. Radosław Plato, Filozoficzne Aspekty Genezy 2011, t. 8, s. 124 [121-135], http://www.nauka-a-religia.uz.zgora.pl/index.php?action=tekst\&id=214 (05.02.2012). 
Termin naturalizm metodologiczny po raz pierwszy ukazał się w druku w artykule „Naturalizm w naukach przyrodniczych”, napisanym przez de Vriesa dla Christian Scholar's Review w 1986 roku. Wcześniej de Vries przez wiele lat posługiwał się tym terminem w trakcie zajęć uniwersyteckich oraz rozmów z kolegami z Wheaton College. Od czasu publikacji termin „naturalizm metodologiczny” przyjął się wśród części naukowców, teologów i filozofów, zajmujących się tematyką nauki i religii. Używa go przychylny temu ujęciu nauki fizyk i teolog Robert Russell, jak również matematyk i filozof William Dembski, który się mu sprzeciwia. ${ }^{2}$ Karl Giberson i Donald Yerxa argumentują, że pogląd ten jest głównym przedmiotem sporu między chrześcijanami, ale twierdzą też, że „spór o naturalizm metodologiczny i teistyczną naukę nie obejmuje przeciętnego naukowca w fartuchu laboratoryjnym $[\ldots]$ ". ${ }^{3}$

Zwolennikami tej koncepcji są między innymi Richard H. Bube, Denis Lamoureux, Howard Van Till, Keith B. Miller i Robert O. Connor, ${ }^{4}$ natomiast przeciwnicy to na przykład Alvin Plantinga, J.P. Moreland i Stephen C. Meyer. ${ }^{5} \mathrm{Ci}$ ostatni odrzucają naturalizm metodo-

\footnotetext{
${ }^{2}$ Por. Robert John Russell, „Eschatology and Scientific Cosmology: From Conflict to Interaction", w: Harry Lee Poe and J. Stanley Mattson (eds.), What God Knows: Time and the Question of Divine, Baylor University Press, Waco, Texas 2005, s. 107; William A. Dembsкi, Intelligent Design: The Bridge Between Science \& Theology, InterVarsity Press, Downers Grove, Illinois 1999, s. 19, 67, 69, 119, 223-224, 257.

${ }^{3}$ Karl W. Giberson i Donald A. YerXa, O gatunkach powstawania. W poszukiwaniu opowieści o stworzeniu, przeł. Dariusz Sagan, Biblioteka Filozoficznych Aspektów Genezy, t. 3, Wydawnictwo MEGAS, Warszawa 2008, s. 220.

${ }^{4}$ Por. Giberson i YerXa, O gatunkach powstawania..., s. 222-223.

${ }^{5}$ Por. Giberson i YerXa, O gatunkach powstawania..., s. 220-221. Jednym z najważniejszych celów Plantingi, Morelanda i Meyera jest zapewnienie w nauce miejsca dla Boga. Jeżeli ktoś wierzy w Boga i stworzenie, to ta wiara powinna wpływać na jego praktykę naukową. Wydaje się, że tę trójkę uczonych jeszcze bardziej interesuje, w jaki sposób wiara może pomóc $\mathrm{w}$ opracowaniu programu badawczego w ramach danej dziedziny nauki. Boga traktują głównie jako przyczynę celową, nie zaś bezpośrednią, ale opowiadają się za takim spojrzeniem na naukę, które dopuszcza możliwość bezpośredniego działania Boga w świecie. Słusznie podejmują oni kwestię podstawowych założeń na temat rzeczywistości, kierujących badaniami naukowymi, mimo iż problem ten należy raczej do dziedziny filozofii, a nie metodolo-
} 
logiczny głównie dlatego, że nie pozostawia w nauce miejsca dla bezpośredniego działania (direct action) Boga. Chcieliby oni, aby oprócz przyczynowości bezpośredniej (immediate causality), nauka brała pod uwagę także przyczynowość ostateczną lub celową. Piszą tak, jakby przekonanie, że nauka powinna zajmować się tylko przyczynami bezpośrednimi, stanowiło współczesną innowację, a przecież przyczyn celowych nie uwzględniała już nauka w sensie zdefiniowanym przez Francisa Bacona (1561-1626) w Novum Organum.

W zasadzie słowo „nauka” (ang. science), pochodzące od łacińskiego słowa scientia, pierwotnie oznaczało „wiedzę”. Kiedy średniowieczni scholastycy uznawali teologię za „królową nauk”, mieli na myśli wszystkie dziedziny wiedzy. Znaczenie słów zmienia się jednak z biegiem czasu pod wpływem czynników kulturowych, w tym rozmaitych poglądów filozoficznych. Dla Platona wiedza zmysłowa była jedynie mniemaniem, ale dla Arystotelesa stanowiła najpewniejszą formę wiedzy. Od czasów średniowiecznych, pod wpływem arystotelesowskiego poglądu na wiedzę, przesiąkniętego myślą Tomasza z Akwinu, słowo „nauka” zaczęło oznaczać wiedzę zmysłową. Od wieku dziewiętnastego terminem tym określano dziedzinę nazywaną niegdyś filozofią przyrody. Z upływem czasu filozofia przyrody otrzymała miano nauki przyrodniczej, a ta w końcu stała się po prostu nauką.

Nauka nie wyklucza innych form wiedzy, a jej kompetencje ograniczają się do opisu wiedzy możliwej do uzyskania drogą obserwacji zmysłowej. Nawet jeśli Bóg działa w fizycznym świecie bezpośrednio, nauce pozostaje opisanie tego, co można zaobserwować za pomocą zmysłów, nie zaś tego, co naukowiec uważa za ostateczną przyczynę zaobserwowanego zjawiska. Powołując się na autorytet Pisma Świętego, ludzie mogą wierzyć, że Bóg ukształtował ich w łonie matki. Aby jednak ten pogląd mógł być naukowy, należałoby opisać, jak

gii naukowej. Ich stanowisko prawdopodobnie nie byłoby tak kontrowersyjne, gdyby de Vries nie zaproponował metody naukowej, która jako swój punkt wyjścia przyjmuje naturalizm. Por. Alvin Plantinga, „Methodological Naturalism?”, Perspectives on Science and Christian Faith, September 1997, vol. 49, no. 3, s. 143-154, http://www.asa3.org/ASA/PSCF/1997/ PSCF9-97Plantinga.html (25.01.2010). 
ten proces przebiega fizycznie w ciele. O dziwo, osoby debatujące nad wartością naturalizmu metodologicznego nie odwołują się ani do artykułu de Vriesa, w którym przedstawił on uzasadnienie tego rozumienia naukowości, ani do Bacona i jego metody naukowej. Mówią po prostu ogólnikowo o „nauce”.

Być może takie samo znaczenie, co uczestnicy sporu o naturalizm metodologiczny, mają ci, którzy poruszają pokrewne zagadnienia, lecz nie używają tego terminu. O ile nam wiadomo, John Polkinghorne, Arthur Peacocke, Stephen Jay Gould, Richard Dawkins, Russell Stannard czy Paul Davies nie posługują się nim. Niektórzy stosują inną terminologię. Peacocke mówi o „teistycznym naturalizmie”, przez który ma na myśli, że „w twórczości Boga w świecie działa często [...] coś, co nazywamy «przypadkiem»”. ${ }^{6}$ Giberson i Yerxa mówią o „,metodologicznym agnostycyzmie". ${ }^{7}$ Plantinga zaś, za Basilem Willeyem, naturalizm metodologiczny określa jako ,prowizoryczny ateizm”. ${ }^{8}$

W artykule „Naturalizm w naukach przyrodniczych” de Vries twierdzi, że naturalizm metodologiczny jest ,jedynie metodą" nauk przyrodniczych i diametralnie różni się od metafizycznego naturalizmu darwinowskiego. ${ }^{9}$ Pisze on:

Naturalizm metodologiczny jest zupełnie odmienny od naturalizmu metafizycznego. Ten ostatni jest perspektywą filozoficzną, która zaprzecza istnieniu transcendentnego Boga. $Z$ naturalizmu metodologicznego nic takiego nie wynika, ponieważ ta metodologia naukowa nawet nie podnosi kwestii istnienia Boga. Niestety, te dwa rodzaje naturalizmu często bywają ze sobą mylone. W rezultacie ludziom niezważającym na subtelności filozoficzne wydaje się, że osiągnięcia nauk przyrodniczych, kierujących się naturalizmem metodologicznym, przema-

\footnotetext{
${ }^{6}$ Arthur PEACOCKE, Drogi od nauki do Boga. Kres naszych wszelkich poszukiwań, przeł. Joanna Gilewicz, Wydawnictwo Zysk i S-ka, Poznań 2004, s. 178, 79, 177-180, 206, 208-209, 211, 236.

${ }^{7}$ Giberson i YerXa, O gatunkach powstawania..., s. 20.

${ }^{8}$ Plantinga, ,Methodological Naturalism...”.

${ }^{9}$ Por. DE VRIES, „Naturalizm w naukach przyrodniczych...”, s. 123.
} 
wiają na rzecz naturalizmu metafizycznego. To nieporozumienie jest godne ubolewania i z pewnością nie znajduje usprawiedliwienia. ${ }^{10}$

De Vries przestrzega, abyśmy nie wikłali się w „gry językowe”, i przypomina, że sprzeczności lub semantyka nie powinny przesłaniać istoty tej idei. Podkreśla on, że chrześcijanie powinni „,przyjmować naturalistyczną metodologię nauk przyrodniczych z entuzjazmem". ${ }^{11}$ Dzięki tej metodologii możemy odkryć wiele tajemnic Boga i oddać mu chwałę. De Vries uczula jednak, że gdy poświęcimy się badaniom naukowym, naszej uwagi nie powinny rozpraszać „teologiczne lub filozoficzne spekulacje”. ${ }^{12}$ Wskazuje, że „naturalizm, rozumiany jako metoda, nie udziela odpowiedzi na żadne pytania filozoficzne lub teologiczne". ${ }^{13}$ Naturalizm metodologiczny ma swoje ograniczenia i nigdy nie odpowie na wielkie pytania typu „Dlaczego?”, natomiast z większą łatwością odpowiada na pytania typu „Jak?”

Nauki przyrodnicze muszą zachować wierność naturalizmowi metodologicznemu, ale w innych dyscyplinach miałby on „katastrofalne skutki". ${ }^{14}$ De Vriesa niezmiernie niepokoi nie tylko kreacjonizm naukowy i ewolucjonistyczny scjentyzm, ale również nieuprawnione próby zastosowania metody naukowej w dyscyplinach spoza nauk przyrodniczych. Wierzy on, że przyjęcie naturalizmu metodologicznego zapobiegnie „,narzucaniu go dziedzinom, do których on się nie nadaje". ${ }^{15}$

\footnotetext{
${ }^{10}$ DE VRIES, „Naturalizm w naukach przyrodniczych...”, s. 123.

${ }^{11}$ DE VRIES, „Naturalizm w naukach przyrodniczych...”, s. 131.

${ }^{12}$ DE VRIES, „Naturalizm w naukach przyrodniczych...”, s. 131.

${ }^{13}$ Korespondencja elektroniczna między Paulem de Vriesem a Chelsea Mytyk, 28 kwietnia 2006.

${ }^{14}$ DE VRIES, „Naturalizm w naukach przyrodniczych...”, s. 132.

${ }^{15}$ Korespondencja elektroniczna między Paulem de Vriesem a Chelsea Mytyk, 28 kwietnia 2006.
} 


\section{Metoda naukowa Francisa Bacona}

W dialogu nauki i religii termin ,naturalizm metodologiczny” odnosi się do wymogu uprawiania nauki tak, jak gdyby Bóg nie istniał, a przynajmniej jakby nie odgrywał żadnej roli w fizycznym świecie. Przypomina naukowcom i teologom o potrzebie obiektywizmu badań. Naturalizm metodologiczny to próba stworzenia neutralnego sposobu myślenia, który rozważania teologiczne releguje poza obręb nauki. Czy jednak rzeczywiście jest to pogląd neutralny, sprzyjający obiektywizmowi? A może w istocie niweczy on dążenia Bacona do opracowania metody naukowej, która byłaby wolna od metafizycznych uprzedzeń?

Szybki rozwój wiedzy o świecie fizycznym, którą nazwano później „nauką", nastąpił wraz z wielkim rozkwitem intelektualnym na początku siedemnastego wieku. Za sprawą takich ludzi jak Kopernik i Kepler pod koniec średniowiecza wytrysnął strumień idei dotyczących ruchu planet, lecz spiętrzoną falę zainicjowała dopiero zaproponowana przez Bacona nowa, rygorystyczna metoda badań fizycznego świata. Bacon uznał, że rozwój tego, co dziś nazywamy wiedzą naukową, nie mógłby dojść do skutku, gdyby naukowcy nie przestali bazować na metafizycznym fundamencie filozofii greckiej. Chociaż istnienie większości nauk zawdzięczamy Grekom, Bacon zauważył, że nauka grecka miała zwykle charakter „,retoryczny”, a nie doświadczalny, prawdy poszukiwano drogą dysput, a filozofowie ,ulegali ambicji i próżności, zbytnio się każdy z nich troszczył o stworzenie własnej sekty i zdobycie popularności”. ${ }^{16}$

Arystoteles i inni greccy filozofowie wyjaśniali „działanie” fizycznego świata, przeprowadzając rozumowanie logiczne, oparte na filozoficznych przesłankach. Stagiryta objaśnił w ten sposób czas absolutny, nieskończoną przestrzeń i wieczną materię świata. Na podstawie swojej koncepcji Nieporuszonego Poruszyciela wytłumaczył doskona-

\footnotetext{
${ }^{16}$ Franciszek BACon, Novum Organum, przeł. Jan Wikarjak, Biblioteka Klasyków Filozofii, Państwowe Wydawnictwo Naukowe, Warszawa 1955, s. 95.
} 
ły, sferyczny kształt ciał niebieskich oraz ich doskonałe, koliste orbity. Arystotelesowski Bóg to narcyz, który spędza wieczność na kontemplacji własnego piękna, podczas gdy cały Wszechświat obraca się wokół niego. Pod koniec średniowiecza nauka polegała na dopasowywaniu obserwacji do systemu metafizycznego Arystotelesa. Bacon nie zaproponował nowej metody po to, by uwolnić naukę od Boga, nie uważał bowiem, że kwestia Boga może w jakikolwiek sposób wstrzymywać rozwój wiedzy. Opracował natomiast podejście do badań nad funkcjonowaniem świata, które opierało się na obserwacji, nie zaś na ideach metafizycznych. Brak miejsca nie pozwala nam na analizę pokrewnej, współczesnej debaty nad tym, czy metoda naukowa w ogóle istnieje, ale już sam fakt, że taka dyskusja się toczy, świadczy o tym, że filozoficzne problemy humanistyki przeniknęły na grunt nauk przyrodniczych i społecznych.

Bacon wyodrębnił różne kategorie przyczyn zjawisk. Metafizyka mówi o przyczynach celowych lub ostatecznych, natomiast obserwacje świata wskazują na bezpośrednie przyczyny w sferze empirii. Idei metafizycznych o tyle nie uznawano za wzajemnie sprzeczne, o ile postrzegano je jako dotyczące innego poziomu doświadczenia. $Z$ drugiej strony Bacon wyraźnie uważał, że niektóre z nich są błędne. Mniej więcej w tym samym czasie Galileusz doszedł do identycznego wniosku w odniesieniu do arystotelesowskiej koncepcji nieba. Metoda naukowa opiera się jednak na paru wielkich założeniach metafizycznych, wywodzących się z wiary biblijnej: (1) istnieje rzeczywisty, poznawalny zmysłowo świat oraz (2) świat ten cechuje się pewnym uporządkowaniem, którego przejawy da się opisać i przewidzieć w taki sposób, że można im nadać miano „praw”. Różnica między metafizycznymi założeniami Bacona a scholastyków polega na tym, że te pierwsze nie obejmują konkretnych wyjaśnień działania świata. Według Bacona wiara w Stwórcę w żaden sposób nie ogranicza tego, do jakich odkryć mogą doprowadzić badania $\mathrm{w}$ tym zakresie. 


\section{Metafizyczne konotacje naturalizmu}

De Vries wolałby, abyśmy - zastanawiając się nad zastosowaniem terminu „,naturalizm” — nie angażowali się w gry językowe, jednak słowa są narzędziami służącymi do przekazywania idei i nie można ich ignorować. Czy naturalizm można uznać za metodę zdobywania wiedzy naukowej, pozbawioną metafizycznych konotacji, z jakimi to słowo zawsze łączono? Rodzina wyrazów natura/naturalny/naturalizm wywodzi się $w$ istocie $z$ tradycji myśli zachodniej, nabrzmiałej ukrytymi filozoficznymi i teologicznymi implikacjami.

Słowo „natura” to poetycki synonim lub metafora doświadczalnego zmysłowo świata - ma ono liczne metafizyczne konotacje, od których wolny jest bardziej naukowy termin „fizyczny”. Zwyczaj określania fizycznej rzeczywistości czy materialnego świata mianem „,natury” wyrósł z alegorycznej poezji szkoły w Chartres. W czasie, gdy arystotelizm przeżywał rozkwit, przedstawiciele tej szkoły żywili platoński pogląd na świat, który dominował przed wiekiem jedenastym. Godzili oni Księgę Rodzaju z platońskim Timajosem, darzyli szacunkiem i badali świat materialny. $W$ ich alegorycznej poezji stworzony porządek fizycznego świata nosi zatem miano Natury — bogini, która na polecenie Boga koryguje to, co nienaturalne. ${ }^{17}$ Łacińskie słowo natura nie odnosi się do fizycznego świata jako takiego, lecz do powstawania, charakteru, konstytucji lub kolei rzeczy. ${ }^{18}$ Inne pokrewne mu określenia to: natalny, natywność i natywny. Wybrawszy słowo natura jako nazwę dla personifikacji porządku fizycznego, poeci sugerowali, że jego charakterem, koleją rzeczy czy „naturą" jest realizacja woli Boga.

\footnotetext{
${ }^{17}$ C.S. Lewis, The Allegory of Love: A Study in Medieval Tradition, Oxford University Press, New York 1958, s. 88. Najważniejsi poeci z Chartres i ich dzieła to: Bernard Silvestris (De Mundi Universitate sive Magacosmos et Microcosmos), Alanus ab Insulis (Anticlaudianus oraz De Planctu Naturae) i Johannes de Altavilla (Architrenius).

${ }^{18}$ Por. etymologię tego słowa w: The Compact Edition of the Oxford English Dictionary I, Oxford University Press, New York 1971, s. 1900.
} 
W języku angielskim słowo „natura”, w wielu swoich znaczeniach, odnosiło się do istotnych przymiotów rzeczy, posiadanych przez nie mocy lub mocy działających w rzeczach. Definicja słowa „natura” w odniesieniu do świata fizycznego, podana w Oxford English Dictionary, ma wysoce metafizyczny wydźwięk: „Twórcza i regulująca siła fizyczna, której przypisuje się działanie w materialnym świecie i którą uznaje się za bezpośrednią przyczynę wszystkich jego zjawisk". ${ }^{19}$ Wittgenstein nauczał, rzecz jasna, że znaczenie słowa określane jest przez sposób jego użycia, nie zaś słownikową definicję. Dzięki zrozumieniu, co naukowcy i inni ludzie mają na myśli, odnosząc pojęcie „natury” do fizycznego świata, możemy zdać sobie sprawę ze związanej z nim nieuświadomionej skłonności do myślenia i mówienia, że natura wykonuje różne działania. Natura, jako świat fizyczny, niczego jednak nie robi. Ona po prostu jest. W naturze zachodzą różne zjawiska, ale ona sama nie podejmuje żadnej inicjatywy. Po prostu istnieje.

Współczesna skłonność do myślenia, że natura jest bytem ożywionym, nie wywodzi się bezpośrednio ze średniowiecznej poezji alegorycznej, w której stworzenie po raz pierwszy spersonifikowano jako Naturę. Skłonność ta ma źródło raczej w Oświeceniu, a spotęgowała ją nowożytna koncepcja racjonalności propagowana przez takich metafizyków jak Hegel, Marks, Nietzsche, Spinoza i Leibniz, którzy tchnęli w Naturę siłę napędową i cel. Wiek dziewiętnasty wypełnił Naturę „zasadą”, która według Gregory’ego Thornbury pełniła funkcję „,substytutu Boga". ${ }^{20}$

Słowo „naturalizm” wzbogaca pojęcie natury o dodatkową treść. $\mathrm{Na}$ pierwszy rzut oka wydawać by się mogło, że niesie ono ze sobą ideę obiektywizmu, ale jest wprost przeciwnie. Naturalizm to pogląd filozoficzny, w myśl którego wszystkie zjawiska można wyjaśnić wyłącznie za pomocą „naturalnych” czy fizycznych przyczyn, bez ucie-

\footnotetext{
${ }^{19}$ The Compact Edition..., s. 1900.

${ }^{20}$ Za tę uwagę Harry Lee Poe jest wdzięczny Gregory'emu Thornbury, z którym regularnie prowadzi dyskusje.
} 
kania się do wyjaśnień metafizycznych. Zauważmy, że naturalizm wcale nie oferuje pomocy $\mathrm{w}$ badaniu fizycznego świata. Mówiąc o „naturalnym” stanie czegoś, mamy na myśli „normalną konstytucję rzeczy", czyli rzeczy takie, jakimi są. Pojęcie konstytucji czegoś nie implikuje jednak, że to coś musi mieć charakter fizyczny. Aby otrzymać pogląd, zgodnie z którym wyjaśnienie „naturalistyczne” wyczerpuje wszystko, co można powiedzieć o danej rzeczy, należy dodać inne rozróżnienie — oddzielić to, co „naturalne”, od tego, co „duchowe".

Metoda naukowa już od dawna opiera się na założeniu, że nauka zajmuje się jedynie badaniem świata fizycznego i tym, czego można dowiedzieć się na podstawie obserwacji zjawisk fizycznych. Naturalizm nie wnosi do metody naukowej niczego, co i tak nie ograniczałoby już nauki do badania takich zjawisk. Głosi natomiast, że przyczyny „,naturalne” czy fizyczne thumaczą wszystkie zjawiska, że tylko naukowa analiza danego zagadnienia prowadzi do uzasadnionych rozwiązań oraz że empiryzm (głoszący, iż wiedza zdobywana jest drogą doświadczenia zmysłowego) to jedyna uprawniona forma wiedzy. Problem $\mathrm{z}$ naturalizmem polega na tym, że w żaden sposób nie przyczynia się do rozwoju wiedzy naukowej i zniechęca do zgłębiania innych rodzajów wiedzy.

Bacon dostrzegł, że metafizyczne wyjaśnienia funkcjonowania świata wstrzymują dalsze dociekania. Pojęcie „,przypadku” to właśnie takie współczesne metafizyczne wyjaśnienie, ,przypadek” nie należy jednak do języka nauki, lecz do języka Las Vegas i Monte Carlo. W ramach naturalizmu „przypadek” stanowi znakomite wyjaśnienie, ponieważ ma zastosowanie w każdej sytuacji. Wyjaśnia wszystko. Jeśli wiemy, że coś zachodzi przypadkowo, to nie musimy prowadzić dalszych badań. Nie ma potrzeby poszukiwać jakiegoś nieznanego jeszcze mechanizmu. Zdarzenie przypadkowe nie ma przyczyny. Nauka zajmuje się jednak odkrywaniem przyczyn - nawet tych, które leżą u podstaw zdarzeń losowych. W tym względzie przyjęcie istnienia Boga znacznie bardziej przyczynia się do rozwoju nauki niż założenie działania przypadku. Bóg zapewnia podstawę dla uporządkowa- 
nia i regularności, które można odkrywać w świecie fizycznym. Przypadek, $\mathrm{z}$ drugiej strony, to przyczyna celowa, która pełni również funkcję przyczyny sprawczej — stanowi metafizyczne wyjaśnienie fizycznych zjawisk!

Naturalizm metodologiczny sugeruje, że badania naukowe należy prowadzić w zgodzie z założeniem, iż Bóg nie odgrywa żadnej roli w świecie fizycznym. Jeżeli jednak metoda naukowa sprowadza się jedynie do obserwacji i opisu fizycznego świata, to po co w ogóle poruszać zagadnienie Boga? Przyjmując naturalizm metodologiczny, naukowiec posiłkuje się stanowiskiem filozoficznym jako metodologią obejmującą idee metafizyczne, które nie mają istotnego znaczenia dla badanego problemu naukowego.

\section{Eksperyment}

Rozpatrzmy prosty eksperyment naukowy. Chcemy dowiedzieć się, ile waży leżący na stole bochenek chleba. Jakiś chłopiec twierdzi, że chleb umieściła na stole jego matka. Inne dziecko mówi, że zrobił to sąsiad z mieszkania obok, a jeszcze ktoś inny przekonuje, że bochenek leżał tam zawsze. Łatwo zauważyć, że żaden $\mathrm{z}$ tych możliwych scenariuszy nie ma wpływu na wagę chleba. Nie trzeba zakładać, że ktoś położył chleb na stole (teizm lub deizm), ani że chleb był tam zawsze (naturalizm), ani nawet że ktoś go tam położył, ale należy ważyć go tak, jakby zawsze leżał na stole (naturalizm metodologiczny). Zważenie chleba w zgodzie $\mathrm{z}$ założeniem, że zawsze był na stole (nawet jeśli uważamy, że ktoś go tam umieścił), nie ma żadnego wpływu na wynik ważenia.

Słowo „natura” to poetycki synonim lub metafora doświadczalnego zmysłowo świata. Służyło także jako jego alegoryczna personifikacja, utożsamiająca rzeczywistość fizyczną z boginią Naturą. Gdy w wiekach osiemnastym i dziewiętnastym ta personifikacja zyskiwała coraz większą popularność, nie oznaczała niczego metafizycznego czy religijnego, ludzie Zachodu na ogół nie wierzyli już bowiem w duchowość boskiego aspektu świata fizycznego. W wieku dwudziestym, za 
sprawą przecięcia się ruchu ekologicznego, skrajnej teologii feministycznej wraz z towarzyszącym jej odrodzeniem kultu bogini matki, jak również skłonności do przypisywania procesowi ewolucji woli oraz zdolności myślenia i podejmowania decyzji, doszło jednak do ponownej sakralizacji fizycznego świata.

Jak na ironię, owa resakralizacja zbiegła się w czasie ze śmiercią poezji w szeroko rozumianej kulturze Zachodu. Ludzie piszący poezję dla siebie i nielicznych elit wciąż stanowią margines społeczeństwa, zaś masy nie czerpią już przyjemności z kontemplowania poezji. Już jej nie rozumieją. Nie przemawia do nich. Umiejętność rachowania i zdolność obserwacji — ,jego runo było białe niczym śnieg...” * to dwa aspekty jednej całości. Nauka polega na symbolicznej reprezentacji i analogii. Śmierć wyobraźni poetyckiej i zastąpienie jej suchą, rzeczową dosłownością nie ubogaca nauki.

Naturalizm zdominował liberalną teologię na przełomie dziewiętnastego i dwudziestego wieku, kiedy to uczeni poszukiwali ,naturalistycznych" wyjaśnień dla zjawisk religijnych. W badaniach biblijnych pojawiła się skłonność do naturalistycznego wyjaśniania cudów, proroctw, objawień, wcielenia Chrystusa i całej gamy innych chrześcijańskich wierzeń. Naturalizm przeczy temu, by jakikolwiek transcendentny byt działał $\mathrm{w}$ doświadczalnym zmysłowo świecie. $\mathrm{Z}$ tego powodu naturalizm ściśle wiąże się z filozoficznym materializmem, głoszącym, że istnieje tylko świat materialny.

Czy naturalizm metodologiczny posuwa naukę naprzód? Czy należy oczekiwać od ateistów, by przyjęli metodologiczny agnostycyzm, dzięki któremu mogliby zachować obiektywizm w pracy naukowej? Nie byłoby to dobre rozwiązanie, ponieważ — podobnie jak w przypadku naturalizmu metodologicznego — do metody naukowej niepotrzebnie wprowadzano by tym samym kwestię Boga.

\footnotetext{
* (Przyp. thum.) Jest to fragment dziewiętnastowiecznej amerykańskiej rymowanki przedszkolnej i szkolnej „Mary Had a Little Lamb”. Autorzy odnoszą się zapewne do przekonania, że rymowanki i muzyka pomagają uczniom rozwijać wyobraźnię przestrzenną, dzięki czemu łatwiej przyswajają wiedzę z zakresu matematyki i nauk przyrodniczych.
} 
W poglądach Richarda Dawkinsa i innych podobnych mu ludzi można dostrzec przekonanie, że jeśli zjawisko zostało opisane, to je wyjaśniono. Przechodzą oni od naturalizmu metodologicznego do materializmu metodologicznego, który w jeszcze większym stopniu odbiega od metody naukowej. Podczas gdy metoda ta ogranicza się do tego, co można empirycznie zaobserwować w naturze, naturalizm metodologiczny zakłada, że to, co wydarza się w empirycznie obserwowalnym świecie, jest wszystkim, co da się poznać, lub wszystkim, co może przyczynić się do zrozumienia danego zjawiska. Co więcej, ludzie słabo znający się na filozofii odnoszą wrażenie, że naturalizm jest prawdziwy i że to właśnie on leży u podstaw nauki.

Dawkins popełnia ten błąd w Bogu urojonym, ${ }^{*}$ gdzie na podstawie teorii, którą nakłada na fakty przed ich sprawdzeniem, z góry określa, czego można dowiedzieć się na temat świata. Taką samą metodą posłużyli się przeciwnicy Galileusza, którzy nałożyli teorię Arystotelesa na wszystkie dane zdobyte dzięki obserwacjom nieba. Taki sam błąd Bacon skrytykował w dziele Novum Organum, w którym wyłożył swoją koncepcję metody naukowej. Bacon doskonale rozumiał, że to nie teologia stanowi ogromne zagrożenie dla wiedzy naukowej (teologia ma przecież inny przedmiot badań), lecz filozofia, bowiem ustanowiła ona schematy myślenia, w świetle których ludzie, nie będąc tego świadomi, postrzegają świat.

Propozycja de Vriesa, aby utożsamić naukę z naturalizmem metodologicznym, wynika z dobrych intencji i dotyka poważnego problemu, mającego źródło w kreacjonizmie naukowym oraz w stanowisku, które nazwaliśmy ewolucjonistycznym scjentyzmem. Tym chrześcijanom, którzy dosłownie interpretując różne fragmenty Biblii upatrują tam wskazania bezpośrednich przyczyn, podejście de Vriesa uzmysławia, że nauka zajmuje się wyłącznie tym, co można odkryć dzięki badaniu fizycznego świata. Tym zaś, którzy na podstawie bezpośrednich przyczyn wnioskują, że istnieje tylko świat fizyczny, pogląd de Vriesa

\footnotetext{
* (Przyp. thum.) Richard Dawkins, Bóg urojony, przeł. Piotr Szwajcer, Wydawnictwo CiS, Warszawa 2007.
} 
uświadamia, że naturalizm jest jedynie metodą badań. Niestety, żaden z tych obozów nie zwraca uwagi na to, co de Vries rozumie pod pojęciem naturalizmu metodologicznego. Kreacjoniści naukowi są wierni hermeneutyce zgodnej z ich wiarą i najpewniej nie porzucą swojego stanowiska na rzecz naturalizmu metodologicznego, chyba że uda się wykazać, że ich interpretacja Biblii jest błędna. Natomiast ludzie pokroju Dawkinsa, którzy pozostają wierni naturalizmowi (oraz materializmowi i ateizmowi), nie sprowadzą naturalizmu do zwykłej metody, wierzą bowiem, że jest to najlepsze ujęcie rzeczywistości.

Naturalizm metodologiczny nie uwalnia nauki od restrykcyjnych wyjaśnień metafizycznych, lecz wzmacnia status naturalizmu jako właściwego metafizycznego wyjaśnienia. A jeśli metoda naukowa opiera się na naturalizmie, to naturalizm musi być prawdziwy. Ten tok rozumowania opisała Barbara Forrest. Sugeruje ona, że filozoficzny naturalizm jest ideą czysto metafizyczną, podczas gdy naturalizm de Vriesa to także epistemologia. Jeśli przyczynowość nadnaturalna istnieje, to naturalizm metodologiczny jest do przyjęcia. $Z$ drugiej strony, jeżeli ostateczną przyczyną jest natura, to niezależna metoda nie jest konieczna, gdyż naturalizm filozoficzny stanowi jedyną logiczną możliwość. A skoro naukowcy nie znaleźli żadnych empirycznych świadectw nadnaturalnych zjawisk lub oddziaływań, to jako najbardziej logiczny wniosek należy przyjąć, że filozoficzny naturalizm ma lepsze uzasadnienie. ${ }^{21}$

Podstawą metody naukowej nie jest oczywiście ani naturalizm, ani żadna inna metafizyka. U jej podstaw leży metafizyczny neutralizm. Naukowcy powinni o tym pamiętać właśnie z tego powodu, że wbrew założeniom ideału oświeceniowego, między tym, co fizyczne, a tym, co metafizyczne, nie istnieje bezkresna, nieprzekraczalna przepaść. Teiści i ateiści łatwo te dwie sfery mylą i mieszają. W sferze metafizycznej poruszamy się niestety dość nieporadnie. Mimo iż większa część ludzkiego doświadczenia ma charakter umysłowy, bardziej

\footnotetext{
${ }^{21}$ Por. Barbara Forrest, „Methodological Naturalism and Philosophical Naturalism: Clarifying the Connection”, Philosophy, Winter 2000, vol. 3, no. 2, s. 7-29.
} 
świadomi jesteśmy własnej fizyczności. Fizyczność definiujemy najczęściej na podstawie poglądów metafizycznych, jednak robimy to dopiero wtedy, gdy w świetle ustalonych wcześniej przekonań na temat tego, czym jest fizyczność, zdefiniujemy najpierw to, co metafizyczne. Potrzebujemy zatem rygorystycznej metody naukowej. Filozofowie mogą natomiast wspólnie z naukowcami badać związek (o ile taki istnieje) między tymi dwiema sferami — fizyczną i metafizyczną.

W eseju poświęconym analizie kilku książek na temat nauki i religii — których autorami są teiści Owen Gingerich i Francis Collins oraz ateiści Daniel Dennett i Richard Dawkins - Cornelia Dean słusznie zauważyła:

W tym momencie wkracza metoda naukowa. Dopóki naukowcy są gotowi formułować hipotezy, opisywać sposób ich testowania, prezentować dane, wyjaśniać sposób ich analizy oraz płynące stąd wnioski, nie powinno mieć znaczenia, czy modlą się do Zeusa, Jahwe, Wróżki Zębuszki czy też do nikogo.

Ich praca będzie mówić sama za siebie. ${ }^{22}$ \\ Harry Lee Poe \\ i Chelsea Rose Mytyk
}

\footnotetext{
${ }^{22}$ Cornelia DEAn, „Faith, Reason, God and Other Imponderables”, The New York Times, 25 July 2006, http://www.nytimes.com/2006/07/25/science/25books.html?_r=3\&pagewanted $=$ all $(26.01 .2010)$.
} 